\title{
Taxonomic and nomenclatural notes on Guatteria australis (Annonaceae)
}

\author{
ADRIANA Q. LOBÃO ${ }^{1}$, RENATO DE MELLO-SILVA², PAUL J.M. MAAS ${ }^{3} \&$ RAFAELA C. FORZZA ${ }^{4}$ \\ ${ }^{1}$ Universidade Federal Fluminense, Departamento de Biologia Geral/Instituto de Biologia, Rua Outeiro de São João Batista, s/n. \\ Campus do Valonguinho. 24020-150, Niteroi, Rio de Janeiro, Brazil; email: alobao@ hotmail.com \\ ${ }^{2}$ Universidade de São Paulo, Departamento de Botânica, Rua do Matão, 277, 05508-090, São Paulo, SP, Brazil \\ ${ }^{3}$ National Herbarium Nederland, Wageningen University branch, Generaal Foulkesweg 37, Wageningen, The Netherlands \\ ${ }^{4}$ Jardim Botânico do Rio de Janeiro, Rua Pacheco Leão, 915, Rio de Janeiro, 22460-030, Rio de Janeiro, RJ, Brazil
}

\begin{abstract}
Guatteria is the largest genus of Annonaceae, comprising ca. 300 species. The genus presents taxonomic problems, and the number of species has been overestimated. Taxonomic revision, description, comments and illustration of G. australis are presented here. As a result, 41 names have been placed in synonymy under G. australis, and three lectotypes are newly designated.
\end{abstract}

\section{Resumo}

Guatteria é o maior gênero da família Annonaceae compreendendo ca. 300 espécies. O gênero apresenta problemas taxonômicos e o número de espécies tem sido superestimado. Revisão taxonômica, descrição, comentários e ilustração de G. australis é apresentada aqui. Como resultado 41 nomes foram sinonimizados com G. australis e três lectótipos designados.

Key words: Atlantic Forest systematics, Annonaceae, Brazilian floristics, Guatteria, Mata Atlantica

\section{Introduction}

Guatteria Ruiz \& Pavón (1794: 85) is the largest genus of the family Annonaceae, comprising 307 species (Erkens et al. 2008). It is distributed from southeastern Mexico south to Bolivia and southern Brazil (Barringer 1984). The genus is characterized by the impressed primary vein on the upper side of the leaves, a pedicel with a distinct suprabasal articulation, more or less equal whorls of imbricate petals, and numerous single-seeded stalked monocarps (Erkens et al. 2006, 2007a).

Fries (1939) authored the last taxonomic revision of the genus, in which 151 species were recognized from Brazil (106 of which he newly described) and the species classified into 30 sections. Fries (1949, 1953, 1959) changed Guatteria infrageneric classification and created two subgenera, Guatteria subg. Anomalantha (monotypic, comprising only G. anomala R.E.Fr.) and Guatteria subg. Guatteria, with 22 sections, including all Brazilian species. In Guatteria subg. Guatteria there are some difficult species complexes such as the $G$. trichoclonia complex (distributed throughout the full range of the genus), the G. schomburgkiana complex (occurring in the Guyana Shield and Amazonian regions), and the G. amplifolia complex (Central America; Erkens 2007b). The close affinities among the species in these complexes are generally confirmed by phylogenetic analyses, although some species might be grouped on the basis of homoplastic characters (e.g., the hairs of the G. trichoclonia complex; Erkens 2007b). 